http://jmscr.igmpublication.org/home/

ISSN (e)-2347-176x ISSN (p) 2455-0450

crossref DOI: https://dx.doi.org/10.18535/jmscr/v7i7.35

\title{
Study of Serum Ferritin Level and its Correlation with Metabolic Syndrome
}

\author{
Authors \\ Dr Arun Kumar ${ }^{1}$, Dr Sumukh ${ }^{2}$ \\ ${ }^{1}$ Medical Officier District Hospital, Jhansi, UP, India \\ ${ }^{2}$ Medical Officier KG Nursing Hospital, Agra, UP, India
}

\begin{abstract}
Introduction: The metabolic syndrome (Syndrome X) consists of a group of metabolic abnormalities that confer increased risk of cardiovascular diseases (CVD) and Diabetes Mellitus (DM). Major features of metabolic syndrome include central obesity, hypertriglyceridemia, low High Density Cholesterol, hyperglycemia and hypertension.

Aim: The aim of the study is to explore the association between serum ferritin level and metabolic syndrome.

Materials and Methods: A total of 210 subjects between the age group 30-60 years were taken for the study. Patients of metabolic syndrome i.e. subjects were diagnosed on the basis of NCEP ATP III criteria. Evaluation of cases and controls was carried out covering four aspects- clinical, anthropometric, biochemical and nutritional. Venous blood samples were collected after a 12 hour fasting period into heparin, citrate and anticoagulant free BD vacutainer tubes. Serum concentration of ferritin were estimated by using micro ELISA test kits. Cases and controls were compared using Chi-square test and unpaired students test and $p$ values were calculated.

Result: Significant relationship was observed between serum ferritin level and components of metabolic syndrome. There was a strong correlation between serum ferritin levels and metabolic syndrome with a $p$ value $<0.001$. Individual components of the metabolic syndrome also showed positive association with the serum ferritin levels ( $p$ value $<0.001$ ).
\end{abstract}

\section{Introduction}

The metabolic syndrome (Syndrome X) consists of a group of metabolic abnormalities that confer increased risk of cardiovascular diseases (CVD) and Diabetes Mellitus (DM). Major features of metabolic syndrome include central obesity, hypertriglyceridemia, low High Density Cholesterol, hyperglycemia and hypertension. Prevalence of the metabolic syndrome varies across the globe, in part reflecting the age and ethnicity of the populations studied and the diagnostic criteria applied. Asian Indians are a high risk population with respect to diabetes and CVD, the numbers are consistently on rise. The prevalence of metabolic syndrome in Asian Indians varies according to the region, the extent of urbanization, lifestyle patterns, and socioeconomic/ cultural factors. Recent data show that about one-third of the urban population in India's major cities have Metabolic syndrome.

Ferritin, one of the key proteins regulating iron homeostasis, is a widely available clinical 
biomarker to evaluate iron status and especially important for detecting iron deficiency. Elevated serum ferritin levels independently predicted incident type 2 diabetes in prospective studies in apparently healthy men and women. Some studies demonstrate the strong associations between ferritin concentrations, obesity and inflammation, that contribute to the development of type 2 diabetes. Most of the previous studies have evaluated only the individual components of metabolic syndrome with serum ferritin levels rather than the clustered condition of metabolic syndrome. The aim of our study is to evaluate the ferritin concentration association with metabolic syndrome and its multiple components.

\section{Materials and Methods}

The prospective and cross-sectionalstudy was conducted in PG Department of General Medicine, Sarojini Naidu Medical College, Agra for 6 months from Aug 2018 to Feb 2019. A written informed consent were taken from the patients included in the study. The study population was patients of metabolic syndrome visiting outpatient department of the hospital.

National Cholesterol Education Program Adult Treatment Panel III (ATP III) criteria of Metabolic Syndrome consists of following components-

1) Central obesity: Waist circumference > $102 \mathrm{~cm}$ for men or $>88 \mathrm{~cm}$ for women.

2) Hypertriglyceridemia: Serum triglycerides $>150 \mathrm{mg} / \mathrm{dl}$.
3) Low HDL cholesterol < $40 \mathrm{mg} / \mathrm{dl}$ for men or $<50 \mathrm{mg} / \mathrm{dl}$ for women.

4) Arterial hypertension $>130 / 85 \mathrm{mmHg}$ or patients on antihypertensive treatment.

5) Hyperglycemia: fasting plasma glucose $=$ or $>110 \mathrm{mg} / \mathrm{dl}$.

Patients with Diabetes Mellitus, hypertension, anemia, dyslipidemia, h/o hemochromatosis (S.Ferritin levels >200ng/ml), h/o blood transfusion, iron or vitamin therapies in last 6 months, raised inflammatory markers .i.e., CRP were excluded from our study. A total of 210 subjects between the age group 30-60 years were taken for the study. Patients of metabolic syndrome i.e. subjects were diagnosed on the basis of NCEP ATP III criteria.Evaluation of cases and controls was carried out covering four aspects- clinical, anthropometric, biochemical and nutritional. Venous blood samples were collected after a 12 hour fasting period into heparin, citrate and anticoagulant free BD vacutainer tubes.

Following investigations were carried out on both patients and controls-

Complete blood counts with peripheral blood smears, blood glucose levels in both fasting and post-prandial state, lipid profile including total cholesterol, high density lipo-protein, low density lipo-protein, very low-density lipo-protein, triglycerides, kidney function tests including blood urea and serum creatinine, urine routine and microscopy, CRP, Serum ferritin, TIBC.

Table 1: Age Distribution of Patients Studied

\begin{tabular}{|l|c|c|c|c|c|c|}
\hline Age groups & Male & & Female & & Total & \\
\hline & No. & $\%$ & No. & $\%$ & No. & $\%$ \\
\hline $31-40$ & 16 & 17.02 & 30 & 17.02 & 46 & 21.9 \\
\hline $41-50$ & 42 & 44.68 & 44 & 44.68 & 86 & 40.95 \\
\hline $51-60$ & 32 & 34.04 & 32 & 34.04 & 64 & 30.48 \\
\hline $61-70$ & 2 & 2.13 & 4 & 3.45 & 6 & 2.85 \\
\hline $71-80$ & 2 & 2.13 & 6 & 5.17 & 8 & 3.81 \\
\hline TOTAL & 94 & 100 & 116 & 100 & 210 & 100 \\
\hline
\end{tabular}

Mean \pm SD $=47.93 \pm 12.03$

There were 210 patients in this study. Majority of patients $86(40.95 \%)$ were in their fifth decade of life in males (42) and females (44). There were only 6 patients between $61-70$ yrs and only 8 patients above 70 yrs of age. 
Table 2: Mean Values of the various Characteristics Studied in Male \& Female

\begin{tabular}{|l|c|c|}
\hline Variables & $\begin{array}{c}\text { Male }(\mathrm{n}=94) \\
\text { Mean } \pm \text { SD }\end{array}$ & $\begin{array}{c}\text { Female }(\mathrm{n}=116) \\
\text { Mean } \pm \text { SD }\end{array}$ \\
\hline Waist circumference $(\mathrm{cm})$ & $93.2 \pm 11.2$ & $84.3 \pm 9.3$ \\
\hline & & $26.42 \pm 2.52$ \\
\hline BMI $(\mathrm{kg} / \mathrm{m} 2)$ & $26.5 \pm 2.23$ & $146.25 \pm 7.82$ \\
\hline Systolic BP $\mathrm{mmHg}$ & $146.55 \pm 8.92$ & $91.61 \pm 5.8$ \\
\hline Diastolic BP $\mathrm{mmHg}$ & $91.57 \pm 8.53$ & $155.4 \pm 9.4$ \\
\hline Triglyceride $\mathrm{mg} / \mathrm{dl}$ & $166.2 \pm 12.53$ & $42.2 \pm 6.12$ \\
\hline HDL $\mathrm{mg} / \mathrm{dl}$ & $38.12 \pm 8.23$ & $128.22 \pm 4.12$ \\
\hline Fasting blood sugar $\mathrm{mg} / \mathrm{dl}$ & $134.12 \pm 3.12$ & $201.3 \pm 22.3$ \\
\hline PPBS mg/dl & $204.8 \pm 32.5$ & $113.78 \pm 11.39$ \\
\hline S.Ferritinng/ml & $142.4 \pm 12.2$ & \\
\hline
\end{tabular}

The above table compares the mean values of various studied in males and females. The mean waist circumference was $93.2 \pm 11.2 \mathrm{~cm}$ and in female was $84.3 \pm 9.3 \mathrm{~cm}$.BMI in male was $26.5 \pm$ $2.23 \mathrm{~kg} / \mathrm{m} 2$ and in females it was $26.42 \pm 2.52$ $\mathrm{kg} / \mathrm{m} 2$.There is no significant difference in the diastolic and systolic blood pressure in male and female group.Triglyceride levels were higher in males
$(166.2 \pm 12.5) \mathrm{mg} / \mathrm{dl}$ as compared to females $(155 \pm 9.4) \mathrm{mg} / \mathrm{dl}$.HDL levels were lower in males $(38.12 \pm 8.23) \mathrm{mg} / \mathrm{dl}$ as compared to females $(42.2 \pm 6.12) \mathrm{mg} / \mathrm{dl}$.Fasting blood sugar was higher in males (134.12 \pm 3.12$)$ than females (128.22 \pm 4.12).Serum ferritin levels were lower in females (113.78 \pm 11.39$)$ as compared to males $(142.4 \pm$ 12.2).

Table 3: Prevalence of Various Components of Metabolic Syndrome in the Study Group

\begin{tabular}{|l|c|c|c|c|c|c|}
\hline Components of metabolic syndrome & $\begin{array}{c}\text { Male } \\
(\mathrm{n}=94)\end{array}$ & $\begin{array}{c}\text { Female } \\
(\mathrm{n}=116)\end{array}$ & $\begin{array}{c}\text { Total } \\
(\mathrm{n}=210)\end{array}$ & 182 & $86.6 \%$ \\
\hline FBG $>100 \mathrm{mg} / \mathrm{dl}$ & 84 & $89.4 \%$ & 98 & $84.4 \%$ & 182 \\
\hline Systolic BP $>130 / 85 \mathrm{mmHg}$ & 74 & $78.4 \%$ & 79 & $68.1 \%$ & 153 & $72.8 \%$ \\
\hline Diastolic BP > 85mmg & 78 & $82.98 \%$ & 80 & $64.4 \%$ & 158 & $74.2 \%$ \\
\hline BMI $>24 \mathrm{mmHg}$ & 79 & $84 \%$ & 106 & $91.3 \%$ & 165 & $78.5 \%$ \\
\hline Waist circumference , M $>90 \mathrm{~cm}, \mathrm{~F}>80 \mathrm{~cm}$ & 70 & $74.4 \%$ & 98 & $84.4 \%$ & 158 & $75.2 \%$ \\
\hline Triglyceride >150 mg/dl & 70 & $74.4 \%$ & 80 & $68.9 \%$ & 150 & $71.4 \%$ \\
\hline HDL, M <40 mg/dl, F<50 mg/dl & 54 & $57.4 \%$ & 45 & $38.7 \%$ & 99 & $47.1 \%$ \\
\hline Diabetic on treatment & 74 & $78,7 \%$ & 92 & $79.3 \%$ & 166 & $79 \%$ \\
\hline Hypertensive on treatment & 59 & $62.7 \%$ & 76 & $60.5 \%$ & 135 & $64.2 \%$ \\
\hline
\end{tabular}

The above table shows the prevalence of various components of metabolic syndrome in males and female patients of the study group. 84(89.4\%) males and 98(84.4\%) females had fasting blood sugar $>100 \mathrm{mg} / \mathrm{dl} .74 \quad(78.4 \%)$ males and $79(68.1 \%)$ females had systolic BP>130 mmhg. Higher number of males 78 (82.98\%) had diastolic $\mathrm{BP}>85 \mathrm{mmHg}$ as compared to females $80(68.4 \%)$. Larger percentage of female 106 $(91.3 \%)$ had BMI> 24 than male $79(84 \%)$.

Central obesity was present in more females 98 $(84.4 \%)$ in comparison to male $70(74.4 \%)$.
Triglyceride level was deranged in larger percentage of males 70 (74.4) than females 80 $(68.9 \%)$. HDL levels were deranged higher percentage of males $54(57.4 \%)$ as compared to females $45(38.7 \%) .74(78.7 \%)$ male and 92 (79.3\%) of female were taking treatment for diabetes. $59(62.7 \%)$ males and $76(60.5 \%)$ females were taking treatment for hypertension. 
Table 4: Number of Components of Metabolic Syndrome of Patients Studied

\begin{tabular}{|l|c|c|c|c|}
\hline $\begin{array}{l}\text { No. of component of } \\
\text { metabolic syndrome }\end{array}$ & Male (N=94) & & Female (N=116) & \\
\hline & No. & $\%$ & No. & $\%$ \\
\hline 3 components & 32 & 34.04 & 38 & 32.76 \\
\hline 4 components & 34 & 36.17 & 42 & 36.21 \\
\hline 5 components & 28 & 29.79 & 36 & 31.03 \\
\hline
\end{tabular}

There were $38(32.7 \%)$ females and $32(34.4 \%)$ 4 components and 36 females (31.04\%) and 28 males with 3 components of metabolic syndrome, $42(36.21 \%)$ females and $34(36.17 \%)$ males with $(29.79 \%)$ males with 5 components of metabolic syndrome.

Table 5: Mean Serum Ferritin according to number of Components of Metabolic Syndrome of Patients Studied

\begin{tabular}{|l|c|c|}
\hline No. of components of MS & S.Ferritin & \\
\hline & Male & Female \\
\hline 3 components & $92.34 \pm 9.76$ & $67.14 \pm 16.84$ \\
\hline 4 components & $130.498 \pm 19.07$ & $115.08 \pm 13.93$ \\
\hline 5 components & $209.38 \pm 27.16$ & $165.54 \pm 16.52$ \\
\hline P trend & $<0.001$ & $<0.001$ \\
\hline
\end{tabular}

The above table correlates the severity of metabolic syndrome in the form of increasing components of metabolic syndrome with serum ferritin levels. It shows that mean serum ferritin levels rising significantly with increasing number of components of metabolic syndrome in both males and females ( $p$ trend $<0.001$ )

\section{Discussion}

Iron plays a key role in many physiological processes, the harmful effect of iron is decreased through binding to proteins, such as ferritin which is involved in the iron homeostasis and acts as an iron storage protein ${ }^{1}$. Serum ferritin concentration is directly related to iron levels for this reason the evaluation of this protein in blood has been used in diagnosis indicator in iron overload related diseases $^{1,2}$. However ferritin levels can also be altered in inflammation, in chronic renal insufficiency and by metabolic disorders. The relationship between serum ferritin and iron overload is still controversial while some studies indicate a causative relationship of the effects of iron overload in several metabolic syndrome complications $^{3,4}$. In the present study there were $116(55.2 \%)$ females \& 94(44.7\%) males. This observation was in concordance with the observation reported by Ramachandran et al ${ }^{5}$ (2003)

Majority of patients $41 \%$ were in the $41-50$ age group i.e in fifth decade and $30.4 \%$ patients were in 51-60 age group. There were only 16 patients above $60 \mathrm{yrs}$ of age. Mean age of the total patients was $47.35 \pm 8.03$. This finding was comparable to the finding of Pemminati and $\operatorname{Adikari}^{6}(2010)$. In study done by BilgilliSebel et $\mathrm{al}^{7}$ all subjects of metabolic syndrome had $\mathrm{BMI}>25 \mathrm{~kg} / \mathrm{m}$, mean BMI in our study was $26.39 \pm 5.78 \mathrm{~kg} / \mathrm{m}$, central obesity was more prevalent in females $98(84.4 \%$ ) as compared to males $70(74.4 \%)$. This is in concordance with the study Ramchandranet $\mathrm{al}^{5}$ which showed $48.6 \%$ prevalence in females and $22.3 \%$ in males. Trigylcerides levels were deranged in larger percentage of males $74.4 \%(70)$ then females $68.9 \%$ (80) and $54.4 \%$ (54) males had decreased HDL levels as compared to only $38.75 \%$ (45) females.This finding is concordant with the study by Jung suchanget $\mathrm{al}^{8}$ which showed higher prevalence of deranged triglycerides and HDL in males.

Among the components of metabolic syndrome elevated blood glucose was the most frequently occurring criteria (83\%).In our study we divided male and female patients into three groups (containing 3,4 and 5 components of metabolic syndrome) and studied the mean serum ferritin levels of each group in males and females 
separately. In similar study conducted by Megan $\mathrm{jehn}^{9}$ it was revealed that the highest prevalence of the metabolic syndrome occurred in those with the higher levels of serum ferritin.

The positive independent association between serum ferritin levels and presence of metabolic syndrome is biologically possible. Iron is involved in multiple cellular processes and is important for the activity of various enzymes but it can also be toxic and cause organic bio-molecular oxidation. Ferritin is a clinical measure of body iron stores. Elevated iron stores may promote oxidative stress that may contribute to cellular damage leading to insulin resistance and abnormal pancreatic beta cell function. Chronic oxidative stress is also associated with oxidation dysfunction of long chain fatty acids in mitochondria, which can lead to hypertriglyceridemia in circulation and excessive triglyceride accumulation in muscle and liver tissue.

In this study we observed a positive association between higher iron stores, measured by serum ferritin levels, and the increasing number of component of the metabolic syndrome. We also observed that individual components of the metabolic syndrome i.e central obesity, elevated blood sugar, hypertension and dyslipidemia correlated well with the increasing leveling of serum ferritin.

\section{Conclusion}

Metabolic syndrome was mostly prevalent in 4150 year age group and was more common in females. Among the components of metabolic syndrome elevated blood glucose levels was the most frequently occurring criteria followed by central obesity then elevated blood pressure and dyslipidemia. There was a strong correlation between serum ferritin levels and metabolic syndrome with a $\mathrm{p}$ value $<0.001$. Individual components of the metabolic syndrome also showed positive association with the serum ferritin levels ( $p$ value $<0.001$ ).

\section{References}

1. W. Wang, M. A. Knovich, L. G. Coffman, F. M. Torti, and S. V. Torti, "Serum ferritin: past, present and future," Biochimicaet Biophysica Acta, vol. 1800, no. 8, pp. 760769, 2010.

2. R. Brudevold, T. Hole, and J. Hammerstrøm, "Hyperferritinemia is associated with insulin resistance and fatty liver in patients without iron overload," PLoS ONE, vol. 3, no. 10, Article ID e3547, 2008

3. C. Bozzini, D. Girelli, O. Olivieri et al., "Prevalence of body iron excess in the metabolic syndrome," Diabetes Care, vol. 28, no. 8, pp. 2061-2063, 2005.

4. R. Moirand, A. M. Mortaji, O. Loréal, F. Paillard, P. Brissot, and Y. Deugnier, "A new syndrome of liver iron overload with normal transferrin saturation," The Lancet, vol. 349, no. 9045, pp. 95-97, 1997.

5. Ramachandra A, Snehalata C, Satyavani K, SivasankariS, Vijay V, Metabolic syndrome in urban Asian Indian adults- a population study using modified ATP III criteri. Diabetes Res ClinPract.

6. Pemminati S, Adikari MR. Prevalance of Metabolic Syndrome using IDF guidelines in semi urban south Indian population of Mangalore. JAPI. Nov 2010;58:674-677.

7. Bilgilisibel, cerebilar Aydan c, doganaylin, karacabaysal. Inverse relationship between adiponectin and plasminogen activator inhibitor-1 in metabolic syndrome patients. Endocrine regulations 2008; vol.42;63-68.

8. JS Chang, SML in, T CHuang, JCJ Chao, YC Chen, WH Pan ana $\mathrm{CH}$ Bai:Serum ferritin and risk of metabolic syndrome : a population based study. Asia Pac J ClinNutr 2013;22(3)400-407

9. Jehn M, Clark JM, Guallar E; Serum ferritin and risk of the metabolic syndrome in U.S. adults. Diabetes Care 27:2422-2428,2004. 